\title{
Sociobiology
}

SHORT NOTE

\section{Occurrence of Hymenoptera on pig carcasses in a tropical rainforest in Central Amazonia, Brazil}

\author{
A SOMAVILLA ${ }^{1}$, JLP SOUZA $^{1,2}$, AO DA SILVA ${ }^{3}$, RLF KEPPLER ${ }^{1}$ \\ 1 - Instituto Nacional de Pesquisas da Amazônia - INPA, Coordenação de Biodiversidade, Manaus-AM, Brazil \\ 2 - Instituto Nacional da Mata Atlântica-INMA, Santa Teresa-ES, Brazil \\ 3 - Instituto de Proteção Ambiental do Amazonas - IPAAM, Manaus-AM, Brazil
}

\section{Article History}

\section{Edited by}

Evandro N. Silva, UEFS, Brazil

Received

11 December 2018

Initial acceptance 27 January 2019

Final acceptance 01 May 2019

Publication date 20 August 2019

\section{Keywords}

Apidae, forensic entomology, Formicidae, Vespidae.

\section{Corresponding author}

Alexandre Somavilla

Instituto Nacional de Pesquisas da

Amazônia - INPA

Coordenação de Biodiversidade

Av. André Araújo, 2936, Petrópolis

CEP: 69.067-375, Manaus-AM, Brasil.

E-Mail: alexandresomavilla@gmail.com

\begin{abstract}
Hymenotpera species may act as necrophagous, consuming decomposing tissues, as predators, when they feed on other immature and adult insects, and parasites of larvae and pupae of dipterans and coleopterans that colonize the carcasses. In this way, the fauna of four Hymenoptera families (Vespidae, Apidae, Icheneumonidae and Formicidae) associated to different decomposition stages of pig carcasses partially submerged in water stream (igarapé) of the terra-firme Amazonian forest are presented. Formicidae were the most abundant insects with 957 individuals collected all directly in the carcass, followed by Vespidae (143), Apidae (88) and Ichneumonidae with nine individuals collected in the suspended trap. Due to the aspect of the injuries caused by some Hymenoptera to the carcasses, they may be mistaken as skin ulcers, burns or abrasions, which may mislead a forensic investigation.
\end{abstract}

Frequently many Hymenoptera visit carcasses in natural environments, and being potential indicators of postmortem interval (PMI), seasonality, and body movement of carcasses (Moretti et al., 2007). They can act as predators when feeding on immature and adult arthropods, such as scavengers, when consuming decaying tissues and parasites of larvae and pupae of dipterans and coleopterans that colonize the carcasses (Oliveira-Costa, 2011).

Succession studies of insect associated with decaying domestic pig carcasses in Medellín, Colombia, detected the presence of Apidae Epicharis Klug, 1807, Eulaema Lepeletier, 1841, Partamona and Apis Linnaeus, 1758 (Wollf et al., 2001; Pérez et al., 2005). Two species of Formicidae and one of Apidae were reported in the succession of cadaveric entomofauna, using pig carcasses, in Buenos Aires, Argentina (Centeno et al., 2002).
In Brazilian Amazonian terra-firme rainforests, bees like Apis mellifera, Trigona, Partamona, Cephalotrigona and Melipona were collected in stages of domestic pig decomposition (Vianna, 2010). In the same region, Agelaia and Angiopolybia wasps were collected in carrion traps within (Silveira et al., 2005). And A. mellifera was also collected associated with pig carcass in the first stages of decomposition, in São Paulo state (Gomes et al., 2007) and Partamona, Trigonisca, Plebeia and Apis in dry forest in Paraíba state (Santos et al., 2014). For ants, an Anoplolepsis longipes colony was used to estimate the PMI of human remains found in a metal box (Goff \& Win, 1997) in Hawaii.

Recently, studies have pointed out the use of social wasps and ants in forensic analyses (Gomes et al., 2007; Moretti et al., 2008, 2011; Somavilla et al., 2019). However, 
there are no published reports on postmortem injuries caused by these wasps. The real importance of necrophagy for brood nutrition in social wasps and ants is difficult to assess, but the skills at rapidly discovering pieces of carcasses (Cornaby, 1974) may suggest carrion is an important source of protein or other nutrients.

In this study, we evaluated the fauna of four Hymenoptera families (Apidae, Vespidae, Icheneumonidae and Formicidae) associated to different stages of decom-position on pig carcass, Sus scrofa, partially submerged in a water stream in the Central Amazonia.

The sampling was carried out on ombrophilous terrafirme forest area at Ducke Reserve, near Manaus, Amazonas, Brazil. The climate in the area is humid tropical, with a mean annual relative humidity around $80 \%$, mean annual precipitation of 1,750-2,500 $\mathrm{mm}$ and mean annual temperature of $26^{\circ} \mathrm{C}$. The vegetation is lowland tropical rainforest, with a closed canopy and shady understory, characterized by the abundance of palm trees (Baccaro et al., 2008).

Samplings were made at Barro Branco water stream (02 55'49.4" S, 59 58'28.1" W), classified as a second order water stream (Delgado, 1996). The collection occurred in two seasonal periods: dry season in July-August of 2009 and rainy season in November-December of 2009. In each experiment, we used three $\sim 45 \mathrm{~kg}$ pig carcasses partially submerged. The animal was taken alive to the study site and was killed with a shot of a $38 \mathrm{~mm}$ caliber pistol in the frontal head. The carcass was placed in an iron cage $(1.00 \times 0.63 \times 0.74 \mathrm{~m} ; 3 \times 3$ $\mathrm{cm}$ mesh opening) to protect the carcass from large vertebrate scavengers. The choice of bait occurred because it is an animal similar to the human, in relation to diet, intestinal fauna, internal anatomy and decomposition patterns (Amendt et al., 2004; Marques, 2008). Part of Hymenoptera was obtained by manual collection with tweezers, and suspended traps (Rafael $\&$ Gorayeb, 1982), installed in the upper part of the iron cage approximately $30 \mathrm{~cm}$ (Figure 1A).

The specimens were identified and compared with the INPA Invertebrate collection material. The voucher Hymenoptera specimens were deposited in the same collection. The experiments were authorized and recorded under authorization number CEP-UFAM n ${ }^{\circ}$ 029/10, by the Ethics Committee on Animal Use, based on the Brazilian Control Committee for Animal Experimentation (CONCEA).

We collected a total of 1,197 specimens in four Hymenoptera families: Vespidae, Apidae, Icheneumonidae (collected in the suspended trap and on the pig carcasses) and Formicidae (collected directly on the pig carcasses). In the rainy season occurred greater abundance of Vespidae, Apidae, Icheneumonidae and in the dry period a greater abundance of Formicidae. Independent of the seasonal period, Formicidae represented the majority of individuals collected (957), followed by Vespidae (143), Apidae (88) and Icheneumonidae with nine individuals (Table 1). There was no variation of Hymenoptera as a seasonal period and according the decomposition stages (Paired T-test, $\mathrm{p}=0.917$ ). Formicidae and Vespidae consumed the pig fresh and, occasionally, predated the immature Calliphoridae (Diptera), and Apidae fed on body fluids, mostly. Ichneumonidae did not participate in the decomposition process.

Table 1. Absolute (N) and relative (\%) abundances of the Hymenoptera taxa collected in July-August (dry season) and November-December (rainy season) of 2009 in three stages (fresh, bloated and active decaying) on pig carcasses in the Ducke Reserve, Manaus, AM, Brazil.

\begin{tabular}{|c|c|c|c|c|c|c|c|}
\hline \multirow[b]{2}{*}{ Taxa } & \multicolumn{3}{|c|}{ Dry season } & \multicolumn{3}{|c|}{ Rainy season } & \multirow[b]{2}{*}{ Total } \\
\hline & fresh stage & bloated stage & $\begin{array}{c}\text { active decaying } \\
\text { stage }\end{array}$ & fresh stage & bloated stage & $\begin{array}{l}\text { active decaying } \\
\text { stage }\end{array}$ & \\
\hline Vespidae & 22 & 10 & & 66 & 45 & & 143 \\
\hline Agelaia angulata & & & & 02 & 05 & & 07 \\
\hline Agelaia constructor & & & & 03 & 02 & & 05 \\
\hline Agelaia fulvofasciata & 05 & 02 & & 12 & 07 & & 26 \\
\hline Agelaia pallipes & 12 & 03 & & 22 & 07 & & 44 \\
\hline Agelaia testacea & 01 & 01 & & 11 & 04 & & 12 \\
\hline Angiopolybia obidensis & & 01 & & 02 & 09 & & 17 \\
\hline Angiopolybia pallens & 04 & 03 & & 14 & 11 & & 32 \\
\hline Apidae & & 20 & 09 & & 38 & 21 & 88 \\
\hline Trigona crassipes & & 15 & 06 & & 29 & 15 & 65 \\
\hline Trigona hypogea & & 05 & 03 & & 09 & 06 & 23 \\
\hline Ichneumonidae & & & 01 & & 02 & 06 & 09 \\
\hline Ichneumonidae sp. & & & 01 & & 02 & 06 & 09 \\
\hline Formicidae & & 291 & 237 & & 172 & 257 & 957 \\
\hline Camponotus femoratus & & 59 & 52 & & 60 & 26 & 197 \\
\hline Crematogaster carinata & & 169 & 142 & & 43 & 126 & 480 \\
\hline Nylanderia sp. & & 63 & 43 & & 69 & 105 & 280 \\
\hline
\end{tabular}



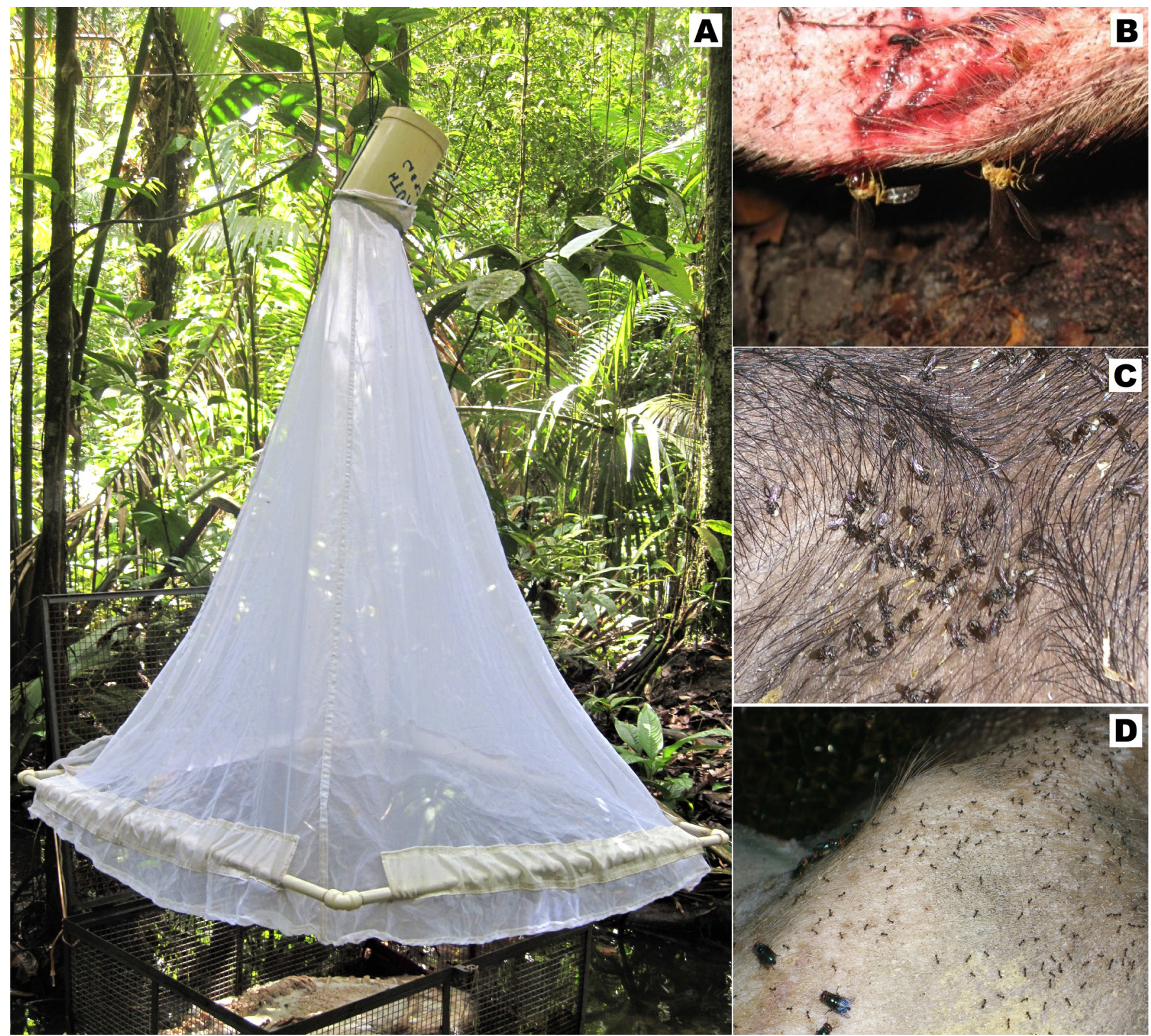

Fig 1. A- Cage model and suspended trap, with pig carcass; B- Wasp Angiopolybia obidensis; C- Bee Trigona crassipes; D- Ant Crematogaster carinata, on pig carcass in Ducke Reserve, Manaus, AM, Brazil.

Vespidae: Agelaia estacea (07 specimens), Agelaia constructor (05), Agelaia fulvofasciata (26), Agelaia pallipes (44), Agelaia estacea (17), Angiopolybia obidensis (12) (Figure 1B) and Angiopolybia pallens (32) used the decaying pig as a source for feed, Because of this habit of removing small pieces of decaying flesh, these species are of forensic entomological concern, since they remove tissue mainly from around the cavities of the carcasses, such as the nose, mouth, ear and anus (Gomes et al., 2007, Somavilla et al., 2019). In addition, some species were observed preying on Calliphoridae (Diptera) that were also colonizing the carcass, other wasps cutting pieces of meat in the natural carcass cavities, such as ears, nose, mouth and anus. Wasps were collected in the initial stages of decomposition, fresh stage (1-24 hours) and bloated stage (24-48 hours).
Decomposing meat can be an important source of food for social wasps and for bees in the Neotropical Region (O'Donnell, 1995). The wasps lacerated the skin and the musculature of the carcasses in the fresh and bloated stages, made by the jaws supported in the hind legs. The areas most affected were close to the jugular, the mucosa of the nose, eyes, mouth and genitalia, and less frequently in regions with lower hair density, such as the foot and abdomen. Wasps feed on the superficial tissues of the carcasses, as well as the eggs and larvae of the first stage of Diptera (Gomes et al., 2007). This behavior has a potential to decrease the larval mass of Diptera on the carcasses and, consequently, reduce the number of older fly larvae, and these older larvae are important to estimate the PMI.

In addition, this behavior can increase the diameter of 
the natural carcass cavities as well as the odor, speeding up the arrival of insects of great importance forensic (flies and beetles), as well as causing lesions that occasionally confuse the expert in the cadaveric analysis process, resembling perimortem lesions by puncture-blunt or puncture-sharp objects. Therefore, it may have a relevance in determining the PMI, if such aspects are not considered (Gomes et al., 2007).

Apidae: Trigona crassipes (65 specimens) (Figure 1C) and Trigona hypogea (23) were collected in the Bloated stage (24-48 hours) and Active decaying stage (48-96 hours) on body fluids, probably as an alternative source of food, and Santos et al. (2014) suggest some bees use animal carcasses as a possible source of water, and salts during inhospitable periods. Probably these species of bees cut fresh pieces of meat in the carcass and when they arrive at their nests, regurgitate for the immature ones.

Regarding social bees, a number of stingless bee species have been observed collecting meat or juices from carcasses, and species of the Trigona hypogea Silvestri group are obligate necrophages, like Trigona hypogea, $T$. crassipes, found in the Amazon, and T. necrophaga, endemic to Panama. (Roubik, 1982; Camargo \& Roubik, 1991). In $T$. hypogea and related species, pieces of flesh are not directly transported as such to the nest, being chewed and ingested at the feeding site, and contents from the crop are subsequently regurgitated to other workers in the nest. Current evidence indicates that flesh is either metabolized into proteinaceous glandular secretions (Camargo \& Roubik, 1991) or stored in protein storage pots mixed with honey (Noll, 1997; Serrão et al., 1997) to be used for nutrition of the larvae.

Ichneumonidae: these are immature parasitoid wasps of Diptera and Coleoptera influencing the decomposition of the corpse, delaying the degradation process, but not actively participating in it (Catts \& Goff, 1992). In our study, they were collected in Advanced decaying stage and Remains stage, in the last four days. Members of this family were also collected during active deterioration and pig remains in Puerto Rico wet forest (Oliveira-Costa, 2011).

Formicidae: Crematogaster carinata (Myrmicinae) (Figure 1D), Camponotus femoratus, and Nylanderia sp. (both Formicinae) (Table 1). Cr. Carinata was the most abundant, with 480 individuals, followed by Nylanderia sp. With 280, and Ca.femoratus with 197 specimens, registered in both seasonal periods, bloated stage (24-48 hours) and active decaying stage (48-96 hours). In an urban area of São Paulo, 77 specimens of Crematogaster, Camponotus and Dolichoderus were collected (Moretti et al., 2007). Although ants be an abundant and constant group on carcasses, they have been the subject of few studies on its importance in criminal investigations.

In the bloated stage, the ants feed on body fluids and then pig tissue. Necrophagous ants can cause mutilation and other injuries when feeding in areas where they remove fragments of skin, small spots or scratches appear
(Campobasso et al., 2009). The influence of ants on the necrophagic community may be significant and will depend on their role as a necrophagous or as decomposer (Moretti et al., 2007). Formicidae occupies diverse ecological associations, being able to act as omnivores and predators, in the latter case they can reduce the decomposition process, already observed in rat carcass by the predation of eggs and larvae of colonizing flies (Moretti \& Ribeiro, 2006; Ramón \& Donoso, 2015). Moreover, in the bloated stage and active decaying stage, individuals of $\mathrm{Cr}$. Carinata preying on eggs and larvae of Diptera in the two seasonal periods. In a fragment of the Atlantic Forest of Pernambuco, Ca. femoratus preyed eggs and larvae of Calliphoridae in the first five days after death in pig carcass (Jiron \& Cartin, 1981).

Knowledge on the behavior and injuries caused by Hymenoptera is important for forensic examiners so as not to mistake the injuries as pre-mortem. This is relevant to crimes involving human beings, since the injuries that Hymenoptera cause on the corpses during the different stages of decay, and the hymenopteran' occurrence per se, can affect the conclusions of forensic investigations. The knowledge on the possible effects of the Hymenoptera as consumers of fresh corpse is still incipient. Further studies with these insects on carrion are required to analyze them as displacement species, consumers of carcasses' resources, and to survey the rates of flesh and fly egg removal, thus assessing their importance to forensic entomology in the Amazon region.

\section{Acknowledgments}

The authors are grateful to Tohnson Sales and Anastácio Ribeiro (in memoriam) for support and help in the fieldwork. Thanks the Programa de Apoio aos Núcleos de Excelência (PRONEX) - CNPq-FAPEAM and the INPA/MCTI/PRJ 12.24 Sistemática Integrada de Insetos Aquáticos, com ênfase em Simuliidae (Diptera: Nematocera) na America do Sul for financial support.

We sincerely thank Fundação de Amparo à Pesquisa do Estado do Amazonas for the postdoctoral scholarship (FAPEAM - Fixam) to A. Somavilla.

\section{References}

Amendt, J., Krettek, R. \& Zehner, R. (2004). Forensic entomology. Naturwissenschaften, 91: 51-65.

Baccaro, F.B, Drucker, D.P., do Vale, J., Oliveira, M.L., C. Magalhães, Lepsch-Cunha, N. \& Magnusson, W.E. (2008). Reserva Ducke, a biodiversidade amazônica através de uma grade. Manaus. In: M.L. Oliveira, F.B. Baccaro, R. BragaNeto \& W.E. Magnusson (Eds), A Reserva Ducke (pp. 1120). Instituto Nacional de Pesquisas da Amazônia.

Camargo, J.M.F. \& Roubick, D.W. (1991). Systematics and bionomics of the apoid obligate necrophages: the Trigona 
hypogeal group (Hymenoptera: Apidae; Meliponinae). Biological Journal of the Linnean Society, 44: 13-39.

Campobasso, C.P., Marchetti, D., Introna, F. \& Colonna, M.F. (2009). Postmortem Artifacts Made by Ants and the Effect of Ant Activity on Decompositional Rates. American Journal of Forensic Medicine and Pathology, 30: 84-87.

Catts, E.P. \& Goff, M.L. (1992). Forensic Entomology in criminal investigation. Annual Review of Entomology, 37: 253-272.

Centeno N. (2000). La entomología forense: aplicaciones, fundamentos y algunos datos sobre la Argentina. Boletín de la Sociedad Entomologica Argentina, 16: 9-11.

Cornaby, B.W. (1974). Carrion reduction by animals in contrasting tropical habitats. Biotropica, 6: 51-63.

Delgado, C.A.V. (1996). Bionomia de Odonata (Insecta) em dois igarapés da Reserva Florestal Adolfo Ducke (ManausAM-Brasil). Dissertação de Mestrado, Instituto Nacional de Pesquisas da Amazônia, Manaus, Amazonas. 84 p.

Goff, M.L. \& B.H. Win. (1997). Estimation of postmortem interval based on colony development time for Anoplolepsis longipes (Hymenoptera: Formicidae). Journal of Forensic Science, 42: 1176-1179.

Gomes, L., Gomes, G., Oliveira, H.G., Morlin Jr., J. J., Desuó, M.M.C., Giannotti, E. \& Von Zuben, C.J. (2007). Occurrence of Hymenoptera on a Sus scrofa carcasses during summer and winter seasons in Southeastern Brazil. Revista Brasileira de Entomologia, 51: 34-39.

Gomes, L. (2010). Entomologia Forense: Novas Tendências e Tecnologias nas Ciências Criminais. Technical Books Editora. Rio de Janeiro. 524 p.

Jirón, L.F. \& Cartín, V.M. (1981). Insect succession in the decomposition of a mammal in Costa Rica. Journal of the New York Entomological Society, 89: 158-165.

Marques, A.M.A. (2008). Entomologia forense: análise da entomofauna em cadáver de Sus scrofa (Linnaeus), na região de Oeiras, Portugal. Dissertação de Mestrado. Universidade de Lisboa, Portugal, $66 \mathrm{p}$.

Moretti, T.Y. \& Ribeiro, O.B. (2006). Cephalotes clypeatus Fabricius (Hymenoptera: Formicidae): nesting habitats and occurrence in animal carcass. Neotropical Entomology, 35: 412-415.

Moretti, T.C., Thyssen P.J., Godoy, W.A.C. \& Solis, D.R. (2007). Formigas coletadas durante investigações forenses no sudeste brasileiro. Biologico, 69: 465-467.

Moretti, T.C., Thyssen, P.J., Godoy, W.A.C. \& Solis, D.R. (2008). Necrophagy by the Social Wasp Agelaia pallipes (Hymenoptera: Vespidae, Epiponini): Possible Forensic Implications. Sociobiology, 51: 393-398.
Moretti, T.C., Giannotti, E., Thyssen, P.J., Solis, D.R. \& Godoy, W.A.C. (2011). Bait and habitat preferences, and temporal variability of social wasps (Hymenoptera: Vespidae) attracted to vertebrate carrion. Journal of Medical Entomology, 48: 1069-1075.

Noll, F.B. (1997). Foraging behavior on carcasses in the necrophagic bee Trigona hypogea (Hymenoptera: Apidae). Journal of Insect Behavior, 10: 463-467.

O’Donnell, S. (1995). Necrophagy by neotropical swarmfounding wasps (Hymenoptera: Vespidae, Epiponini). Biotropica, 27: 133-136.

Oliveira-Costa, J. (2011). Entomologia forense: quando os insetos são vestígios. Editora Millenium, Campinas, Brasil. 502 p.

Patel, F. (1994). Artifact in forensic medicine: postmortem rodent activity. Journal of Forensic Sciences, 39: 257-260.

Pérez, S., Duque, P. \& Wolff, M. (2005). Successional behaviour and occurrence matrix of carrion-associated arthropods in the urban area of Medellín, Colombia. Journal of Forensic Sciences, 50: 1-7.

Rafael, J.A. \& Gorayeb, I.S. (1986). Tabanidae (Diptera) da Amazônia I. uma nova armadilha suspensa e primeiros registros de mutucas de copas de árvores. Acta Amazônica, 12: $232-236$.

Ramón G. \& Danoso, D.A. (2015). The role of ants (Hym.: Formicidae) in forensic entomology. REMCB, 36: 19-26.

Roubick, D.W. (1982). The ecological impact of nectarrobbing bees and pollinating hummingbirds on a tropical shrub. Ecology, 63: 354-360.

Santos, W.E., Carneiro, L.T., Alves, A.C.F., Creão-Duarte, A.J. \& Martins, C.F. (2014). Stingless Bees (Hymenoptera: Apidae: Meliponini) Attracted to Animal Carcasses in the

Brazilian Dry Forest and Implications for Forensic Entomology. Sociobiology, 61: 490-493. doi: 10.13102/ sociobiology.v61i4.490-493

Silveira, O.T., Esposito, M.C., Santos, J.N. \& Gemaque Jr., F.E. (2005). Social wasps and bees captured in carrion traps in a rain forest in Brazil (Hymenoptera: Vespidae, Apidae). Entomological Science, 8: 33-39.

Somavilla, A., Linard, V. \& Rafael, J.A. (2019). Social wasps (Vespidae: Polistinae) on carcasses of Rattus norvegicus (Mammalia: Muridae) in the Central Amazonia, Brazil: possible forensic implications. Revista Brasileira de Entomologia, 63: 18-21. doi: 10.1016/j.rbe.2018.12.001

Wolff, M., Uribe, A., Ortiz, A. \& Duque, P.A. (2001). Preliminary study of forensic entomology in Medellín, Colombia. Forensic Science International, 120: 53-59. 